\begin{tabular}{|ll|}
\hline & $\begin{array}{l}\text { International Journal of Advanced Engineering, Management and Science } \\
\text { (IJAEMS) }\end{array}$ \\
INF & $\begin{array}{l}\text { Peer-Reviewed Journal } \\
\text { P U B L IC A T I O N }\end{array}$ \\
& ISSN: 2454-1311 / Vol-7, Issue-8; Aug, 2021 \\
& Journal Home Page: https://ijaems.com/ \\
& Article DOI: $\underline{\text { https://dx.doi.org/10.22161/ijaems.78.3 }}$ \\
\hline
\end{tabular}

\title{
Effects of Farm Mechanization on the Lives of Rice Farm Workers of Cabanatuan City, Nueva Ecija
}

\author{
Lester Lee R. Alvaro ${ }^{1}$, Maria Kristina S. Angeles ${ }^{2}$, Ericson C. Celis ${ }^{3}$, Violy S. Dela \\ $\mathrm{Cruz}^{4}$, Jeremie Jean DL. Ebron ${ }^{5}$, Ivy V. Espiritu ${ }^{6}$, Ma. Germina Esquivel-Santos ${ }^{7}$
}

\author{
1,6Philippine Center for Postharvest Development and Mechanization - \\ Science City of Muñoz, Nueva Ecija \\ ${ }^{2,5}$ Land Bank of the Philippines - Cabanatuan City, Nueva Ecija \\ ${ }^{3}$ GM Bank of Luzon, Inc. - Cabanatuan City, Nueva Ecija \\ ${ }^{4}$ Philippine Rice Research Institute - Science City of Muñoz, Nueva Ecija \\ ${ }^{7}$ Nueva Ecija University of Science and Technology-Nueva Ecija
}

Received: 12 Jul 2021; Received in revised form: 11 Aug 2021; Accepted: 17 Aug 2021; Available online: 23 Aug 2021

\begin{abstract}
The effects of farm mechanization on the lives of rice farm laborers in Cabanatuan City, Nueva Ecija, were investigated in this descriptive study. Snowball sampling and a survey questionnaire with a consent form were used to collect data. Frequency count, percentages, and weighted mean were utilized to treat and analyze the data. The study's findings found that farm mechanization benefited farmer machine operators in earning more money through faster operations and that they are still regularly employed to work during cropping seasons. Despite this, the respondents see a considerable decrease in the number of rice field laborers.
\end{abstract}

Keywords-Agriculture, farm mechanization, income, labor productivity, rice farmworkers.

\section{INTRODUCTION}

Agriculture has been one of the greatest discoveries that helped shape human civilization and survived up to this date. According to Llorente et al. (2018), agriculture has been performed by humans for approximately 10,000 years, and practices have been altered according to human needs and preferences. All goods for consumption are products or by-products of agriculture. It helps to sustain an economy through the provision of commodities, income sources, and trading. The agricultural industry is a major industry that drives an economy, especially those countries closely tied with agricultural activities. As reported by the Philippine Statistics Authority (2020), although the Agriculture, Forestry and Fishing sector was the lowest contributor among three major sectors of the economy, it recorded a share of 9.2 percent in the Gross Domestic Product (GDP) in 2019, an important indicator of the economic performance of a country. The Philippines is endowed with natural resources such as arable land and channels of rivers suitable for agricultural farming. Palay, being the major crop in the country, has the largest area harvested with 4.65 million hectares in 2019. Nueva Ecija topped ranked with 336 thousand hectares of rice area harvested. Farming is still widely practiced in the province, being the top producer of palay in 2019. Although industrialization has significantly diminished farm areas, remaining rice farmlands are thriving to support rice consumption of the country. There is now an increasing awareness among Filipino farmers with regards to the advantages of utilizing mechanization technologies in the agricultural production system. According to Bautista et al. (2017), Philippine farmers seem to recognize the many advantages of using farm machines over manual, even if these are expensive and will certainly displace laborers. Moreover, government policies on agriculture are now gearing towards food self-sufficiency and security through the adoption and utilization of technologies to improve crop and labor productivity. Amongo and Larona (2015) stated that the invention of machinery on rice farming, greatly aided the quality of production; from the use of carabao then to tractors, 
manual planting to the use of mechanical rice transplanters, and manual harvesting transitioning to mechanical rice reapers and harvesters. Mechanized farming also reduced the cost of palay production, as a huge chunk of the cost came from the manual labor of farmworkers. The goal of mechanization is to reduce labor on rice farming. According to the Philippine Center for Postharvest Development and Mechanization (2019), the projected benefit of using farm machinery is reducing the production cost of palay by $\mathrm{Php} 2.00$ to $\mathrm{Php} 3.00$ per kilogram by using an accurate, effective, and complete set of machinery. The government is promoting the use of machinery in farming to help improve the quality and reduce the cost of production of palay. Republic Act 10601 also known as the Agricultural and Fisheries Mechanization Law of 2013 (AFMech Law) has strengthened the commitment of the government to boost the adoption and utilization of agricultural mechanization technologies to modernize the agricultural sector and to be at par with the ASEAN neighbors. It is hoped that the AFMech Law will aggressively push the implementation of sustainable agricultural mechanization to increase agricultural production to ensure food security, safety, and sufficiency. Other mechanization programs implemented by the Department of Agriculture, along with private enterprises venturing into service rental of machinery gave the boost on the promotion of the use of farm machinery. These vastly change the landscape of farming, from traditional to modern. Farm owners benefit from mechanized farming as it improves the efficiency of rice farming and helps to lower the production cost. However, there will be some sectors that will fall behind due to the adoption of mechanization. Schmitz and Moss (2015) stated that the introduction of new technologies results in losers and gainers. Rice farmworkers, those not owning farmland and providing hired labor, are also affected by these changes. New technologies will continue the trend toward displacing or replacing farm labor. Schulte and
Howard (2019) further stated that technology will bring less work, make workers redundant, or end work by replacing workers. It is widely stated that manual workers are the most harmed by technological developments. The researchers aim to study the effects induced by mechanized farming on rice farmworkers. The degree of effect and how farmworkers act to mitigate these are of great value that some concerned institutions should look upon and consider. This study integrates on the other side of the development and deals with the losers from technological change.

\section{METHODOLOGY}

The study is Descriptive in nature which focuses on determining the effects of farm mechanization on rice farmworkers of Cabanatuan City, Nueva Ecija. The instruments utilized were survey questionnaires with a consent form and snowball sampling wherein the method is purely based on referrals and extensively used when a population is unknown. The Registry System for Basic Sectors in Agriculture (RSBSA) was established to collect information for farmers, farmworkers, and fisherfolk. On the evaluation of Reyes and Gloria (2017), the Registry is useful, but the general concerns are: it seems that the RSBSA failed to cover all farmers, farmworkers, and fisherfolk; the registry lacks technical specifications; and that some information on hectarage and another status might be inaccurate. Nevertheless, the researchers conducted the study with at least 10 rice farm workers per barangay namely, Brgy. Lagare, Brgy. Bangad, Brgy. Bakod Bayan, and Brgy, Kalikid Norte in Cabanatuan City, Nueva Ecija. These are among the barangays with the highest number of rice farm machinery recorded at Cabanatuan City Agriculture Office. A total of 50 respondents were gathered with data. Basic descriptive statistics such as frequency count, percentages, and weighted mean were used.

\section{RESULTS AND DISCUSSION}

\section{Effects of Farm Mechanization on Rice Farm Workers of Cabanatuan City, Nueva Ecija}

\subsection{Labor Productivity of the Respondents}

Table 1. As to Labor Productivity of the Respondents

\begin{tabular}{llll}
\hline \multicolumn{1}{c}{ Statement } & WM & VI \\
\hline 1. I am frequently hired to work on rice farms & 2.80 & Agree \\
2. I learned to operate rice farm machinery & 2.64 & Agree \\
3. My knowledge of rice farming increased because of the adoption of rice & 2.58 & Agree \\
farm machinery. & 2.30 & Disagree
\end{tabular}




\begin{tabular}{lll}
\hline \multicolumn{1}{c}{ Statement } & WM & VI \\
\hline machinery. & 2.62 & Agree \\
5. It is easy to find farm owners who will hire my farm service. & 2.76 & Agree \\
6. I allot a long period of time on the farm working per day. & 2.56 & Agree \\
7. I can finish working on a wide area of rice farms a day. & 2.76 & Agree \\
8. My farm work gets easier and faster because of modern rice farm & 2.38 & Disagree \\
9. I hachinery. & 3.02 & Agree \\
10. I am regularly hired to work on rice farms during the cropping season. & $\mathbf{2 . 6 4}$ & Agree
\end{tabular}

Table 1 shows the responses of the respondents regarding the effects of farm mechanization on their labor productivity, "I am regularly hired to work on rice farms during cropping season" got the highest weighted mean of 3.02 with a verbal interpretation of "agree", and "there is an increasing number of farmworkers due to modern rice farm machinery" got the lowest weighted mean of 2.3 with a verbal interpretation of "disagree". The findings show that respondents are still working regularly at rice farms every cropping season during this period of implementation and adoption of mechanization and modern technologies on rice farming. But respondents see a notable decrease in numbers of farmworkers due to farm mechanization, those displaced workers are already excluded in this informal work sector. Basic data from Decent Work Statistics-Philippine
(DeWS-Philippines,2018) shows that the employment share of agriculture has been steadily falling, the decrease in agriculture's employment share has recently accelerated. Cited as the framework of this study: the "Dual Sector Model of Economic Development" points out that human labor normally shifts from agriculture into a modern industry. The existing labor surplus in the agricultural sector due to the huge population further expands in connection with the adoption of modern farm machinery in exchange for manual labor. The model assumed that few workers leaving the agricultural sector would have virtually no impact on the production output due to low labor productivity, attaining the balance on productivity between the modern industrial sector and traditional agricultural sector.

\subsection{Income of the Respondents}

Table 2. As to Income of the Respondents

\begin{tabular}{lllc}
\hline \multicolumn{1}{c}{ Statement } & WM & VI \\
\hline 1. I am earning enough as a rice farm worker. & 2.04 & Disagree \\
2. I am receiving fair compensation based on the difficulty of my work on rice & 2.56 & Agree \\
& $\begin{array}{l}\text { farms. } \\
\text { 3. } \quad \text { Rice farm machinery aided in increasing the earnings I could receive by }\end{array}$ & 2.60 & Agree \\
working on farms. & 2.78 & Agree \\
4. It is quick to earnmoney on the farm working due to the use of modern farm & 2.16 & Disagree \\
5. It is easy to save money by working on rice farms. & 2.14 & Disagree \\
6. I seldom borrow money. & 2.46 & Disagree \\
7. I can afford to buy my basic needs. & 2.62 & Agree \\
8. My family and I eat adequately every day. & 2.02 & Disagree \\
9. I do not need to look for another source of income & 2.32 & Disagree \\
10. I can save money every cropping season. & $\mathbf{2 . 3 7}$ & Disagree \\
\hline General Weighted Mean & &
\end{tabular}


In relation to the income of the respondents as rice farmworkers, "It is quick to earn money on the farm working due to the use of modern farm machinery" got the highest weighted mean of 2.78 with a verbal interpretation of "agree", and "I do not need to look for another source of income" got the lowest weighted mean of 2.02 verbally interpreted as "disagree". This means that the respondents, composed of 56 percent who tried to operate machines during their farm work, suggest that it is easier and quicker to gain income with the use of machinery than manual labor alone. As stated by Srisompun et al. (2019), aside from the reduction of labor cost, the aid of rice farm machinery made farming faster and enables the cultivation of the larger area. Faster and efficient farming leads to a quick gain of income to a worker operating a farm machine. The respondents imply that, although it is quick to gain income with the help of farm machines, they still needed to look for another source of income. Aside from being seasonal work, poverty has always been tied up to the agricultural sector in the Philippines. A poverty study by Reyes et al. (2012) estimated that the incidence of poverty among agricultural households $(57 \%)$ is thrice than that of the non-agricultural households (17\%).Making agricultural households strive and dedicate more effort to earn for living.

\section{Rice Farm Workers' Ways to Deal with the Effects of Farm Mechanization.}

Table 3. As to Ways on Dealing amidst Farm Mechanization

\begin{tabular}{llcc}
\hline \multicolumn{1}{c}{ Statement } & $f$ & Percentage \\
\hline 1. & Operate rice farm machinery. & 28 & $56 \%$ \\
2. Look for rice farm work in other places. & 30 & $60 \%$ \\
3. Work on other high-value crop farms. & 33 & $66 \%$ \\
4. Borrow capital to start farming own rice crop and other high-value crops. & 22 & $44 \%$ \\
5. Rent an agricultural land to start farming own rice crop and other high-value & 6 & $12 \%$ \\
$\quad$ crops. & 5 & $10 \%$ \\
6. Buy agricultural land. & 36 & $72 \%$ \\
7. Raise livestock. & 5 & $10 \%$ \\
8. Be a rice trader. & 8 & $16 \%$ \\
9. Officially stop on rice farm working. & 41 & $82 \%$ \\
10. Find an alternative source of income aside from working on rice farms. & & \\
\hline
\end{tabular}

Table 3 shows the responses regarding the ways of dealing with the effects of farm mechanization, "Find an alternative source of income aside from working on rice farms" which got the highest number of responses with 41 responses equivalent to $82 \%$ of the respondents. Although workers are regularly hired to work on the farm during the cropping period and those who operate the machine easily gain income with the help of farm machinery. They still needed to find an alternative source of income due to the seasonal and informal setting of the work they do. There is also a continuous decline in the number of farmworkers in general, hence the need to find an alternative job outside the agricultural sector. A combined $24 \%$ of the respondents listed "construction worker" and "tricycle driver" as the most frequent alternative jobs outside the sector of agriculture. According to Charlton and Taylor (2016), it is a worldwide trend that as countries' per capita incomes increase, their workforces shift from agriculture to non-agricultural industries. Industrial growth is expected to continue to uptrend the demand for nonfarmworkers, leading to higher non-farm wages.

\section{Proposed Programs that will address the Effects of Farm Mechanization on Rice Farm Workers}

1. The Local Government Unit should have an exclusive registry system for agricultural farm workers in Nueva Ecija that could help on extending immediate support to the workers and for better program targeting.

2. The implementing agencies and units should establish a stronger information dissemination system to ensure that the existing programs will be effectively implemented and be delivered accordingly to the rightful beneficiaries.

3. Other concerned public and private institutions to create other livelihood and skills training, and more job opportunities to those farmworkers not qualified as beneficiaries on the existing government programs in Nueva Ecija. 


\section{CONCLUSIONS AND RECOMMENDATIONS}

The following conclusions were drawn from the abovementioned results of the study:

1. Respondents denote that they are still regularly hired to work on rice farms every cropping season amidst the adoption of farm mechanization. But respondents also see a significant decline in numbers of rice farm workers, those who are categorized as labor surplus in the agricultural sector are no longer working on farms.

2. Rice farmworkers earn quicker due to faster operations with the use of farm machinery. Though most of them still needed to find other sources of income.

Based on the findings and conclusions, the following were suggested:

1. Rice farmworkers could improve their knowledge and skills on operating farm machinery, through participation in workshops and training (Mina, Subia \& Ermita, 2020) conducted by the government and through experience gained from other farm machine operators, to further increase their farm productivity.

2. Rice farm workers may also diversify their skills aside from farming, through skills training provided by the government and gained experiences, to have more job opportunities and source of income.

3. Future researchers could explore the study on a larger scopeor focus particularly on the agricultural farm workers (Subia, et al, 2019).

\section{REFERENCES}

[1] Amongo, R.C., \&Larona, M.L., (2015), Agricultural Mechanization Policies in the Philippines. Beijing: United Nations Centre for Sustainable Agricultural Mechanization. Retrieved from https://citeseerx.ist.psu.edu/viewdoc/download?doi=10.1.1. 731.7041\&rep=rep1\&type $=$ pdf

[2] Bautista, E.G., Kim, J., Kim, Y., \& Panganiban, E., (2017), Farmer's Perception on Farm Mechanization and Land Reformation in the Philippines. Journal of the Korean Society of International Agriculture 29(3), 242-250. doi:10.12719/KSIA.2017.29.3.242

[3] Charlton, D., \& Taylor, J.E., (2016), A Declining Farm Workforce: Analysis of Panel Data from Rural Mexico. American Journal of Agricultural Economics 0(0): 1-23; doi: 10.1093/ajae/aaw018

[4] Llorente, M., Olivar, R., \&Briceño, I., (2018), Farming for Life, Quality, and Sustainability: A Literature Review of Green Care Research Trends in Europe. Int. J. Environ.
Res. Public Health, 15(6): 1282. doi: 10.3390/ijerph15061282

[5] Mina, J., Subia, G. \&Ermita, P. (2020). Value Chain Analysis of Slipper Industry in the Footwear Capital of the North. International Journal of Supply Chain Management. Vol.9, No.5, 178-183.

[6] Philippine Center for Postharvest Development and Mechanization, (2019), RCEF Mechanization Program $F A Q$. Retrieved from https://rcef.philmech.gov.ph/

[7] Philippine Statistics Authority, (2020), Agricultural Indicators System, Economic Growth: Agriculture. ISSN2012-0435. Retrieved from https://psa.gov.ph/content/agricultural-indicators-systemoutput-and-productivity-0

[8] Philippine Statistics Authority, (2018), Decent Work Statistics (DeWS) - Philippines, Summary Tables (1995-2017). Retrieved from: http://www.psa.gov.ph/sites/default/files/attachments/ird/sp ecialrelease/DeWS\%202018 092818 rev 0.pdf

[9] Philippine Statistics Authority, (2020), Palay and Corn: Area Harvested. PSA OpenSTAT. Retrieved from https://openstat.psa.gov.ph/PXWeb/pxweb/en/DB/DB_2E CS/0022E4EAHC0.px/

[10] Reyes, C.M., \& Gloria, R.B. (2017), Evaluation of the Registry Service for Basic Sectors in Agriculture, PIDS Discussion Paper Series, No. 2017-03, Philippine Institute for Development Studies (PIDS), Quezon City. Retrieve from http://hdl.handle.net/10419/173580

[11] Reyes, C.M., Tabuga, A.D., Asis, R.D. \&Datu, M.G. (2012), Poverty and Agriculture in the Philippines: Trends in Income Poverty and Distribution. PIDS Discussion Paper Series No. 2012-09. Makati City: Philippine Institute for Development Studies. Retrieve from https://dirp4.pids.gov.ph/ris/dps/pidsdps1209.pdf

[12] Schmitz, A., \& Moss, C.B., (2015), Mechanized Agriculture: Machine Adoption, Farm Size, and Labor Displacement.AgBioForum, 18(3), 278-296. Retrieved from

https://mospace.umsystem.edu/xmlui/bitstream/handle/103 55/48143/MechanizedAgriculture.pdf

[13] Schulte, P., \& Howard, J., (2019), The Impact of Technology on Work and the Workforce. Retrieved from https://www.ilo.org/safework/events/safeday/33thinkpieces /WCMS_681603/lang--en

[14] Srisompun, O., Athipanyakul, T., \&Somporn, I., (2019), The Adoption of Mechanization, Labour Productivity and Household Income: Evidence from Rice Production in Thailand. TVSEP Working Paper, No. WP-016, Leibniz Universität Hannover, Thailand Vietnam Socio Economic Panel (TVSEP), Hannover. Retrieved from http://hdl.handle.net/10419/208384

[15] Subia, G., Mina, J., Diaz, R., Campos, Jr. R.,\&Quijano, G.(2019). Re-Engineering on the

[16] Production of Surrogate Feeds for Broiler Chickens (Gallus-Gallus Domesticus): its Effects on Broilers' Live and Carcass Weights and Consumption Cost. International Journal of Environment, Agriculture and Biotechnology 
(IJEAB) Vol-4, Issue-

3,http://dx.doi.org/10.22161/ijeab/4.3.4 ISSN: 2456-1878.

[17] The Official Gazette, (2013), R.A. 10601: An Act Promoting Agricultural and Fisheries Mechanization Development in the Country. Retrieved from https://www.officialgazette.gov.ph/2013/06/05/republicact-no-10601/ 